\title{
Diagnosis of Systemic Scleroderma in a Patient with Leg Ulcer
}

\author{
Gang San Ju, Kyung Min Son, Woo Young Choi, Ji Seon Cheon \\ Department of Plastic and Reconstructive Surgery, Chosun University College of Medicine, Gwangju, Korea
}

\begin{abstract}
Systemic scleroderma is an autoimmune disease that affects connective tissue in internal organs and the skin with thickening and fibrosis. When afflicting internal organs, the disease leads to reduced quality of life and even morbidity. Meanwhile, systemic scleroderma of the skin is often indicative of the same disease in internal organs. One symptom of systemic scleroderma of the skin is ulcers, mainly reported on fingers and less so on legs. This makes systemic scleroderma difficult to diagnose when patients present with only a leg ulcer. Here we report a case of a leg ulcer in a 79-year-old woman who was ultimately diagnosed with systemic scleroderma.
\end{abstract}

Keywords: Early diagnosis; Leg ulcer; Scleroderma, systemic

서론

전신경화증은 혈관에 손상을 입히고, 결합 조직에 콜라겐이 과다 생성 및 축적되면서 섬유화 가 진행되는 자가 면역질환이다[1-4]. 전신경화증의 유병률은 $0.007 \%$ 부터 $0.053 \%$ 까지이며 나 라마다 다르나 미국이 유럽, 일본, 대한민국보다 유병률이 더 높으며, 5 년 생존율은 $74.9 \%, 10$ 년 생존율은 $62.5 \%$ 로 높은 사망률을 보인다[4,5].

전신경화증 초기에 레이노 현상(Raynauds phenomenon)은 대부분의 환자에게 나타나며, 전 신경화증 환자 중약 $50 \%$ 에서 피부궤양이 발생한다. 피부궤양이 심화될 경우에는 감염과 괴사 가 발생하고 절단까지 할 수 있다. 피부궤양은 손가락궤양이 많이 보고되었고, 그 외 하지나 다 른 부위의 피부궤양은 드물게 보고되었다[1,2]. 또 피부와 피하조직을 주로 침범하는 국소성 전 신경화증과 다르게, 피부와 피하조직 그리고 내부 장기까지 빠르게 침범하는 전신성 전신경화 증은 여러 내부 장기들에 침범하면 환자들의 삶의 질과 생명을 위협할 수 있다 [2,4].

본 연구에서는 외상으로 발생한 하지 피부 창상 치료과정 중에 전신경화증을 진단한 예가 드물어 이를 보고하고자 한다. 연구 및 사진 사용에 대한 서면 동의서는 환자로부터 얻었다.

\section{증 례}

과거에 전신경화증을 진단받지 않은 79세 여자환자가, 내원 한 달 전 탁자에 좌측 정강이를 부 딪혀 창상이 발생했다. 다른 병원에서 한 달 동안 치료했으나 호전을 보이지 않아서, 치료 및 피 부이식을 위해 본 병원에 입원하였다. 환자는 고혈압 때문에 이뇨제와 혈압 강하제를 복용하 고 있었고, 당뇨, 흡연력, 음주력은 없었다. 또 수술을 위해 입원 당시 시행한 혈액검사, 심전도검 사, 단순흥부방사선사진, 폐컴퓨터단층촬영, 심초음파 등의 검사에서 약간의 간질성폐질환과 폐동맥고혈압이 진단되었다. 처음 내원할 때, 하지 피부 창상의 크기는 $5 \times 5 \mathrm{~cm}^{2}$ 이었으며 창상 주위에 발적과 부기가 있었고, 녹농균이 동정되었다(Fig. 1). 입원 후 2 주 동안 변연절제술과 드 레싱 치료를 지속하였으며(Figs. 2-4), 이후 창상에서 균이 동정되지 않았다. 변연절제술 시행 시, 출혈과 통증소견은 다른 피부 창상 환자들과 유사하였으나, 하루 혹은 이틀이 지나면 정상 육아조직이 아닌 하얀 조직들이(Fig. 3) 창상 전체를 덮는 경과가 반복되었다.

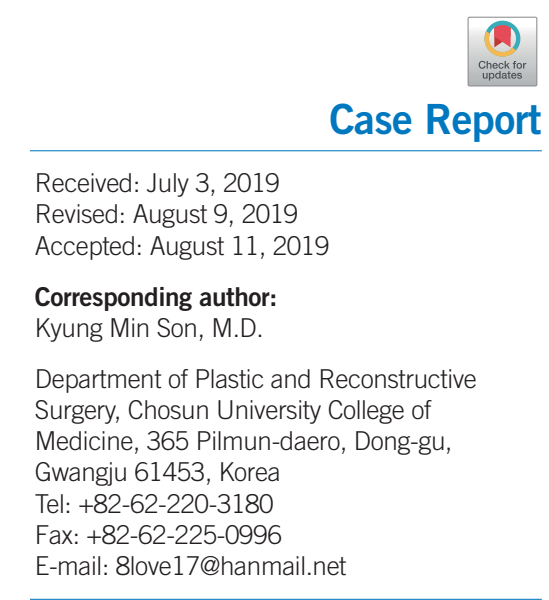

This is an Open Access article distributed under the terms of the Creative Commons Attribution Non-Commercial License (http://creativecommons.org/licenses/by-nc/4.0/) which permits unrestricted non-commercial use, distribution, and reproduction in any medium, provided the original work is properly cited.

C 2019 Korean Wound Management Society 


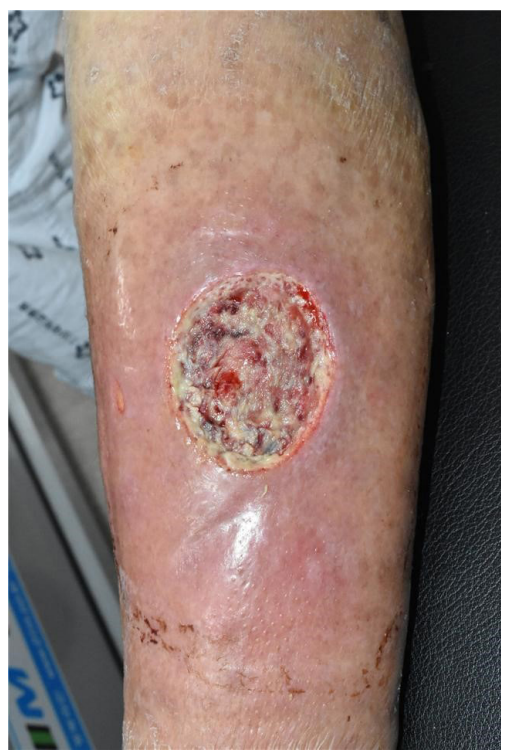

Fig. 1. The 1 st day of hospitalization. An approximately $5 \times 5$ $\mathrm{cm}^{2}$-sized ulcer on left lower leg. Swelling and erythema observed around skin ulcer.

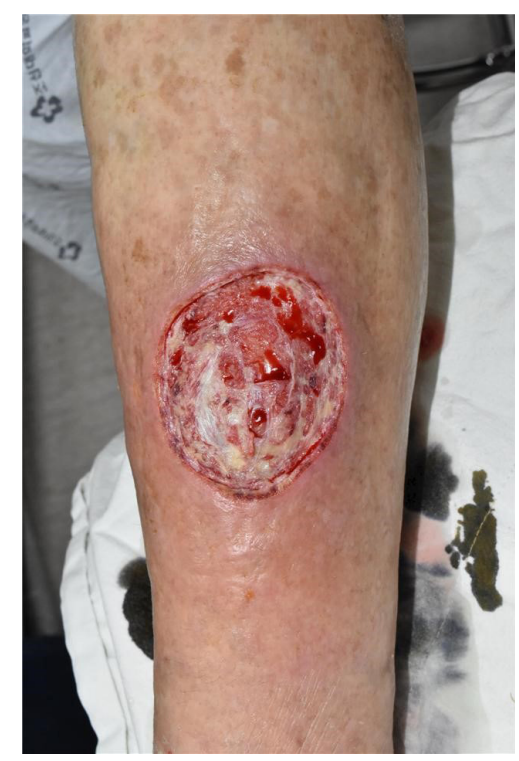

Fig. 2. The 7th day of hospitalization. Swelling and erythema decreased around skin ulcer.

지속적인 치료에도 위와 같은 증상이 반복되어서 하지 창상에서 조직검사를 시행하였다. 입원 시, 신체 검사상 외상으로 발생한 하지 피부 창상 외 다른 창상은 없었고, 전신적 질환의 가능성을 열어 두고 여러 문진을 다시 시행하였다. 그 결과 과거 레이노 현상이 있었으며, 신체검사를 통해 레이노 현상과 손가락 끝 피부가 정상인보다 좀 더 두꺼워진 것을 확인하였다. 추가로 시행한 anti-centromere antibody test에서 양성반응이 나왔고, 조직검사 결과에서는 괴사를 동반한 만 성 궤양, 염증을 동반한 육아조직과 섬유증이 나왔다(Fig. 5). 임상증

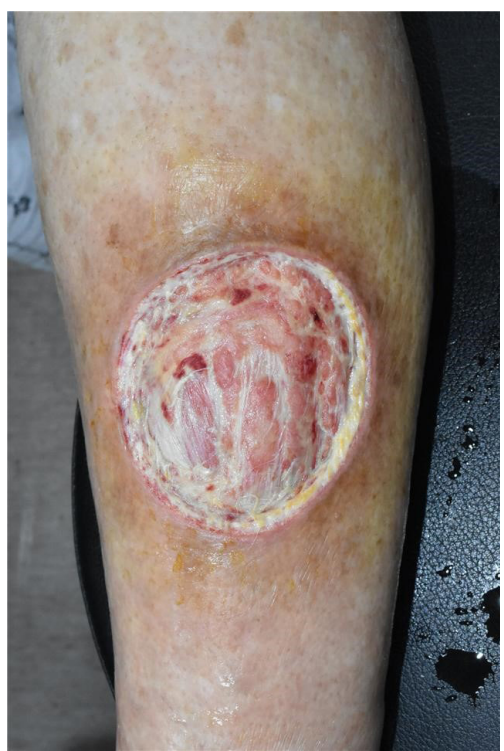

Fig. 3. The 14th day of hospitalization. Swelling and erythema had been resolved, but the amount of inflamed granulation and fibrosis on the skin ulcer had increased.

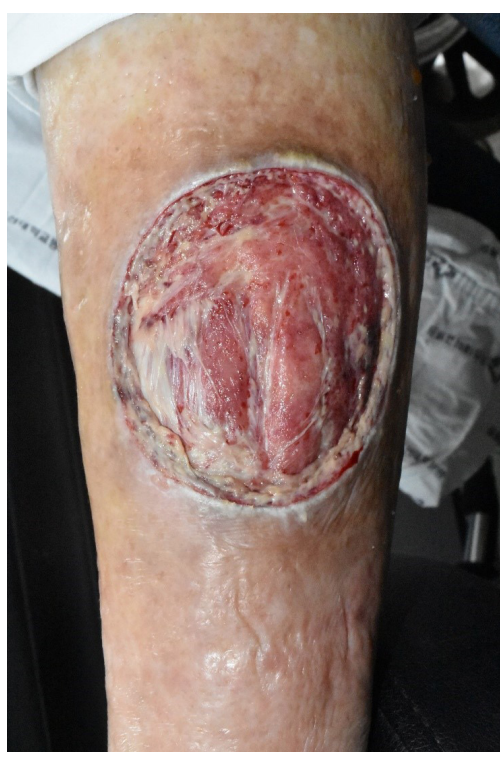

Fig. 4. The 40th day of hospitalization. Inflamed granulation and fibrosis on skin ulcer decreased.

상과 검사결과 American College of Rheumatology/European League Against Rheumatism collaborative initiative (ACR/EULAR) criteria에 부합하여 광범위 전신경화증으로 진단하였으며, 내부 장기들이 섬유 화가 진행되어 있어 기능 저하를 막기 힘든 상태였다. 환자가 호흡곤 란 및 통증을 호소하여 류마티스, 신장, 심장, 호흡기 전문의와 상의 후, 증상 조절을 하기 위해 이뇨제와 진통제로 치료하였으나 내부 장 기들의 급격한 기능 저하로 입원 후 45 일째 다발성 장기부전으로 사 망하였다. 


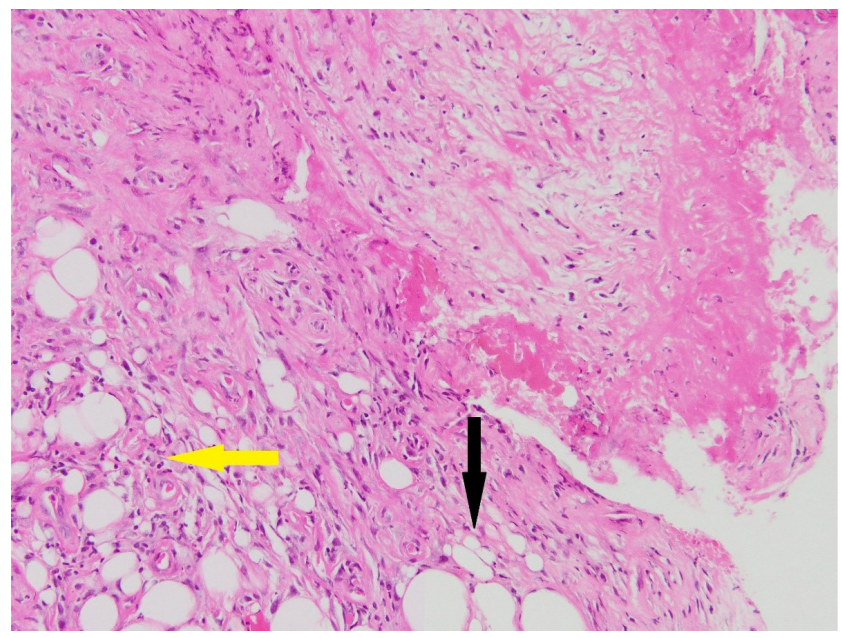

Fig. 5. Pathology findings. Mononuclear inflammatory cells within the intradermal adipose tissue (yellow arrow, collagen; black arrow, dermal adipocytes; H\&E, ×200).

\section{고 찰}

전신경화증은 발병 원인이 정확히 밝혀지지 않은 드문 질환으로 혈 관, 내부 장기, 피부에 콜라겐이 과도하게 생성 및 축적되어 섬유화되 는 자가 면역질환이다. 특히 폐, 신장, 심장, 소화 기관과 같은 내부 장 기에 침범하게 되면 환자들의 삶의 질을 저하시키고 생명을 위협한다.

전신경화증은 국소성과 전신성으로 나뉘어지며, 과거에 국소성 전 신경화증은 주로 안면부 피부가 두꺼워지고 내부 장기를 침범하지 않아서 피부에 국한적으로 영향을 준다고 여겨졌으나, 최근에는 피 부 외 다른 내부 장기들에도 영향을 준다고 알려졌다. 또한 폐동맥고 혈압의 높은 유병률을 보이며, 치료하지 않을 경우 5-10년 이내 치명 적인 예후가 나타난다. 전신성 전신경화증은 주로 팔꿈치나 무릎 근 위부에서 피부가 두꺼워지는 양상이 나타난다. 또, 피부의 침범은 내 부 장기 침범과 연관성이 높으며, 특히 심장, 신장, 폐에 침범할 경우 5 년 이내 사망할 수 있다. 그러나 병의 초기에 진단하고 치료를 하면 내 부장기의 영구적 손상과 사망을 늦출수 있다[4,6].

전신경화증은 ACR/EULAR criteria를 이용하여 진단을 내릴 수 있 으며[3,7], 레이노 현상은 전신경화증의 초기에 발생할 수 있는 가장 흔한 증상이지만, 모든 전신경화증 환자들에게서 발생하지는 않는다 $[4,6]$.

전신경화증에서 발생한 피부궤양은 치료가 더디며 재발이 흔하 고, 치료가 되지 않고 지속될 경우 감염과 괴사로 진행할 수 있다. 손 가락 끝에서 가장 잘 발생하고, 하지나 다른 곳의 발생률은 낮다. 피부 궤양은 모든 전신경화증 환자들에게 발생하지 않으며, 발생 시기도 전신경화증을 진단받고 수년 후 발생하기 때문에 발견 당시 병이 진 행됐을 수 있다. 위에서 언급한 레이노 현상, 피부궤양, 그리고 진단에 도움이 되는 손발톱 주름, 피부가 두꺼워지는 증상은 전신경화증에 서 나타나는 외형증상이지만, 모든 전신경화증 환자들에게 나타나 지 않기 때문에 진단이 어렵다[1,3,6,8].
전신경화증 치료는 전신치료와 국소치료로 나눌 수 있으며, 전신 치료로는 병의 침범부위, 진행상태에 따라 결정된다. 경증인 경우 calcium channel blockers, prostanoids, phosphodiesterase 5 inhibitors 등 의 혈관확장제를 aspirin과 함께 사용할 수 있으나, beta blocker는 말 단 괴사를 악화시킬 수 있다. 중증의 간질성폐질환이나 진행하는 피 부병변일 경우 cyclophosphamide, mycophenolate, rituximab 등의 면 역 억제제를 사용할수 있다. 이외 다수의 장기들이 침범될 수 있기 때 문에 각 분야의 전문의와 함께 상의하여 치료하는 것을 추천한다 [2,6,9,10].

국소치료로는 정상 조직이 손상되지 않게 죽은 조직이나 감염된 조직에 변연절제술을 시행하고, 습윤 드레싱을 유지하며, 감염균이 동정되면 그에 맞는 항생제를 사용한다. 또한 통증 완화를 위해 진통 제를 사용하며, 혈관확장제와 고압산소치료도 궤양치료에 도움이 된 다[2,4,10,11]. 손끝 피부궤양을 치료하여도 지속적으로 재발하거나 악화되어 활동에 제약이 생기는 경우에는 말초 교감신경절제술을 시 행해 볼 수 있다. 그러나 치료 후에 다시 재발하거나 병변 부위를 절단 하는 사례도 있다[10,11]. Calcinosis가 발생하면 통증 조절을 먼저 시 행하며, 효과가 없을 경우 수술적 절제, 부피감소술, $\mathrm{CO}_{2}$ laser vaporization 그리고 체외 충격파쇄석술을 시행할 수 있다. 전신경화증 환 자에게 발생한 피부궤양은 호전 속도가 느리며, 완전히 치료되기까지 수년의 시간이 걸리기도 한다. 이 중 하지 피부궤양에 대해 보고된 연 구는 많지 않고, 연구마다 차이가 있지만 하지 피부궤양 발생 원인의 $40 \%$ 에서 $50 \%$ 정도가 혈관 침범이라고 한다 $[1,8,12]$. 이를 해결하기 위 해서 부분층 피부이식술을 하기 전에 경피경관 혈관성형술, 정맥절 제술을 시행하였고, 수술 부위에서 좋은 결과와 빠른 회복속도를 보 였다[12].

전신경화증은 발생이 드물며, 예후가 좋지 않은 자가 면역질환이 다. 모든 전신경화증 환자들에게 레이노 현상, 손발톱주름, 피부가 두 꺼워지는 증상, 피부궤양 등이 나타나지는 않으며, 피부궤양이 발생 하였을 경우에는 내부 장기나 혈관까지 침범했을 수도 있다. 하지만 초기에 전신경화증을 진단하고 치료하면 내부 장기의 영구적 손상 과 사망을 늦출 수 있다. 전신경화증에서 발생한 피부궤양은 주로 상 지나 손가락에서 발생하기 때문에 하지에 발생한 피부궤양에 대한 보고는 찾기 힘들었다. 본 증례는 외상으로 발생한 하지 창상 환자 치 료 중에 전신경화증을 진단하게 되었고, 이에 만성창상 치료 시, 본 증 례와 유사한 병변의 환자가 있을 경우 초기에 전신경화증을 감별 및 진단할수 있게 도움이 되고자한다.

\section{Conflict of interest}

No potential conflicts of interest relevant to this article are reported.

\section{Acknowledgments}

Gang San Ju https://orcid.org/0000-0003-1954-7850 
Kyung Min Son https://orcid.org/0000-0001-5825-0270

Woo Young Choi https://orcid.org/0000-0001-8849-1569

Ji Seon Cheon https://orcid.org/0000-0001-8555-5088

\section{References}

1. Bohelay G, Blaise S, Levy P, et al. Lower-limb ulcers in systemic sclerosis: a multicentre retrospective case-control study. Acta Derm Venereol 2018;98:677-82.

2. Giuggioli D, Manfredi A, Lumetti F, et al. Scleroderma skin ulcers definition, classification and treatment strategies our experience and review of the literature. Autoimmun Rev 2018;17: 155-64.

3. Alivernini S, De Santis M, Tolusso B, et al. Skin ulcers in systemic sclerosis: determinants of presence and predictive factors of healing. J Am Acad Dermatol 2009;60:426-35.

4. Distler O, Cozzio A. Systemic sclerosis and localized scleroderma: current concepts and novel targets for therapy. Semin Immunopathol 2016;38:87-95.

5. Kang GW, Jung KH, Lee YS, et al. Incidence, prevalence, mortality and causes of death in systemic sclerosis in Korea: a nationwide population-based study. Br J Dermatol 2018;178:e379.

6. Saketkoo LA, Magnus JH, Doyle MK. The primary care physi- cian in the early diagnosis of systemic sclerosis: the cornerstone of recognition and hope. Am J Med Sci 2014;347:54-63.

7. van den Hoogen F, Khanna D, Fransen J, et al. 2013 classification criteria for systemic sclerosis: an American College of Rheumatology/European League Against Rheumatism collaborative initiative. Ann Rheum Dis 2013;72:1747-55.

8. Blagojevic J, Piemonte G, Benelli L, et al. Assessment, definition, and classification of lower limb ulcers in systemic sclerosis: a challenge for the rheumatologist. J Rheumatol 2016;43: 592-8.

9. Attinger CE, Janis JE, Steinberg J, et al. Clinical approach to wounds: débridement and wound bed preparation including the use of dressings and wound-healing adjuvants. Plast Reconstr Surg 2006;117(7 Suppl):72S-109S.

10. Cohen JM, Sibley RA, Chiu ES, et al. Advances in upper extremity scleroderma wound care. Adv Skin Wound Care 2018; 31:446-55.

11. Hughes M, Herrick AL. Digital ulcers in systemic sclerosis. Rheumatology (Oxford) 2017;56:14-25.

12. Hafner J, Schneider E, Burg G, et al. Management of leg ulcers in patients with rheumatoid arthritis or systemic sclerosis: the importance of concomitant arterial and venous disease. J Vasc Surg 2000;32:322-9. 